\title{
Fatal cerebral and cardiac infarction due to embolism of a mobile thrombus from aorta sinotubular junction atheroma in a 40-year-old female
}

\author{
V. Kavalerchyk ${ }^{1, A-F}$, M. Kolesnyk ${ }^{\star 2, A, C-F}$, M. Woehlke ${ }^{4, B}$, A. Staudt ${ }^{1, B}$, \\ A. Hagendorff ${ }^{3, C, E}$
}

${ }^{1}$ Helios Kliniken Schwerin, Klinik für Kardiologie und Angiologie, Schwerin, Germany, 2Zaporizhzhia State Medical University, Zaporizhzhia, Ukraine, ${ }^{3}$ Universitätsklinikum Leipzig, Klinik und Poliklinik für Kardiologie, Leipzig, Germany, ${ }^{4}$ Helios Kliniken Schwerin, Institut für Pathologie, Schwerin, Germany

A - research concept and design; B - collection and/or assembly of data; C - data analysis and interpretation; D - writing the article; $\mathrm{E}$ - critical revision of the article; $\mathrm{F}$ - final approval of the article

Strokes in young adults present a challenging problem in terms of care and social impact. Most of cases in this cohort are classified as strokes of uncertain etiology. Application of multimodality diagnostic approach could help in the estimation of risk factors and underlying mechanisms. Simultaneous acute cardio-cerebral infarction is a rare manifestation, especially in young individuals. Large artery atherosclerosis should be excluded as a potential cause. Transesophageal echocardiography plays an important role in the diagnostic algorithm.

The current article presents a clinical case of a fatal acute cardio-cerebral infarction in a 40-year old female without previous cardiovascular diseases and negative family history. Transesophageal echocardiography identified a large mobile thrombus at the sinotubular junction of ascending aorta. Transthoracic echocardiography revealed regional akinesia of the inferior wall, despite normal electrocardiogram. The autopsy findings confirmed co-occurrence of thromboembolic stroke in the right middle cerebral artery area and left ventricular inferior myocardial infarction due to thrombosis of the right coronary artery. This case documents an exceedingly rare phenomenon in this cohort of a cardio-cerebral thromboembolism due to single atherosclerotic plaque destabilization.

\section{Фатальний інфаркт мозку та міокарда внаслідок емболії мобільного тромбу з атероми синотубулярного з'єднання аорти в 40-річної жінки}

\section{В. Кавалерчик, М. Колесник, М. Вьольке, А. Штаудт, А. Гаґендорфф}

Інсульти в молодому віці - складна проблема з точки зору тактики ведення пацієнтів і соціальних наслідків. Більшість випадків у цій групі класифікуються як інсульти з невизначеною етіологією. Застосування мультимодального діагностичного підходу може допомогти в оцінюванні факторів ризику та основних механізмів. Поєднання інсульту з гострим інфарктом міокарда в молодому віці виявляють украй рідко. Атеросклероз великих артерій повинен бути виключений як потенційна причина розвитку цього стану. Черезстравохідна ехокардіографія відіграє важливу роль у діагностичному алгоритмі.

У цій статті представлений клінічний випадок фатального поєднання гострого інсульту та інфаркту міокарда в 40-річної жінки без попередніх клінічних проявів серцево-судинних захворювань та обтяжливого сімейного анамнезу. Під час черезстравохідної ехокардіографії виявили великий рухливий тромб в області синотубулярного з'єднання висхідної аорти. За допомогою трансторакальної ехокардіографії виявили акінезію нижньої стінки лівого шлуночка, незважаючи на відсутність змін на електрокардіограмі. Результати аутопсії підтвердили одночасний розвиток тромбоемболічного інсульту в басейні правої середньої мозкової артерії та інфаркту міокарда нижньої стінки лівого шлуночка внаслідок тромбозу правої коронарної артерії. Цей випадок документує надзвичайно рідкісний для цієї вікової категорії фатальний епізод кардіо-церебральної тромбоемболії внаслідок дестабілізації однієї атеросклеротичної бляшки.
Key words: sinotubular junction atheroma, mobile thrombus, cerebral infarction, myocardial infarction, young age.

Zaporozhye medical journal 2020; 22 (4), 583-586

*E-mail: zsmumk@gmail.com

Киючові слова: атерома синотубулярного з'єАнання, мобільний тромб, інфаркт мозку, інфаркт міокарда, момодий вік.

Запорізький медичний журнал. 2020. T. 22, № 4(121). C. $583-586$

Ключевые слова: атерома синотубулярного соединения, мобильный тромб, инфаркт мозга, инфаркт миокарда, молодой возраст.

Запорожский медицинский журнал. 2020. T. 22, № 4(121) C. $583-586$

В данной статье представлен клинический случай фатального сочетания острого инсульта и инфаркта миокарда у 40-летней женщины без предшествующих клинических проявлений сердечно-сосудистых заболеваний и отягощенного семейного анамнеза. При проведении чреспищеводной эхокардиографии был обнаружен большой подвижный тромб 
в области синотубулярного соединения восходящей аорты. С помощью трансторакальной эхокардиографии выявлена акинезия нижней стенки левого желудочка, несмотря на отсутствие изменений на электрокардиограмме. Результаты аутопсии подтвердили одновременное развитие тромбоэмболического инсульта в бассейне правой средней мозговой артерии и инфаркта миокарда нижней стенки левого желудочка вследствие тромбоза правой коронарной артерии. Этот случай документирует чрезвычайно редкий для данной возрастной категории фатальный эпизод кардио-церебральной тромбоэмболии вследствие дестабилизации одной атеросклеротической бляшки.

Strokes in young adults comprise $10-15 \%$ of all cerebral infarctions [1]. Most of events are classified as strokes of undetermined etiology. Some studies demonstrated that large artery atherosclerosis is the cause in $4-21 \%$ of patients in this cohort [2]. Nevertheless, it often remains underdiagnosed due to "silent" course of atherosclerotic vascular disease. Application of multimodality diagnostic techniques may result in fewer patients being classified as uncertain etiology. Here we present a clinical case of fatal stroke in a young female without previous cardiovascular history.

\section{Clinical case}

An unconscious 40-year-old female was admitted to the hospital with clinics of left-sided hemiparesis. She had not previous known cardiovascular diseases and her family history was negative as well. The preliminary diagnosis of "right middle cerebral artery stroke" was estimated and the patient was hospitalized to the stroke unit. The computer tomography confirmed a large thrombus formation in the proximal right middle cerebral artery (rMCA), which was partially removed by thrombectomy and thrombus aspiration (Fig. 1). Laboratory findings presented increased C-reactive protein and high sensitive troponin T. Tests for thrombophilia were negative. Electrocardiogram showed sinus tachycardia and complete right bundle branch block. Transthoracic echocardiography illustrated mild reduced left ventricular function with regional akinesia of the inferior wall. No relevant valvular heart disease was present. Transesophageal echocardiography (TEE) found a large mobile thrombotic formation at the sinotubular junction (STJ) of the right aortic sinus (Fig.2,3; Supplementary video 1,2 online). The echo contrast study revealed no intracardiac shunt, no signs of endocarditis and no thrombus in the left atrial appendage documented by TEE (Fig. 4). Additionally, bronchopneumonia was documented by clinical and radiological findings.

Decompressive craniotomy with duraplasty was performed due to refractory intracranial hypertension. Despite therapy, the patient died 6 days after admission. The pathological findings included a recent thromboembolic stroke in the area of rMCA sized $60 \times 50 \times 50 \mathrm{~mm}$ and residual 5-mm thrombus in the rMCA. Significant leftwards displacement of the midline structures was observed with signs of severe cerebral edema (Fig. 5). Autopsy showed only mild sclerosis of the aorta and the supraaortal branches as well as mild coronary atherosclerosis. There was a distinct endothelial lesion in the middle of a circular 10-mm atheroma at the STJ of the right aortic sinus with a residual adhesive 3-mm thrombus (Fig. 6,7). A 17-mm long adherent thrombus was found at the ostium of the right coronary artery with findings of a recent inferior myocardial infarction sized $70 \times 50$ mm (Fig. 8). In addition, a purulent absceding bronchopneumonia due to gram-positive cocci was documented.

\section{Discussion}

As many as 1 out of every 6 strokes occurs in a young adult [3]. Age below 45 is the mostly used criteria for young stroke. The vast majority of events in this cohort are classified as strokes of undetermined etiology. However, application of multimodality diagnostic approach could estimate the underlying cause in most of cases. The FUTURE study analyzed the risk factors of cerebral infarction in young individuals [4]. According to their findings, patients aged $\geq 35$ years were more likely to have large artery atherosclerotic disease than patients below 35 years (11.6\% vs. $2.9 \%$, $\mathrm{P}<0.05)$. TEE plays an important role in patients with stroke of uncertain etiology. It can reveal atherosclerotic plaques in the aortic arch, which often protrude into the lumen and have mobile components in a high percentage of cases. Aortic arch atheroma can be seen in some young adults but its incidence and severity increase with age. The SPARC study analyzed a random sample of 581 people over age of 44 years [5]. All participants had TEE, and atheroma was identified in $51.3 \%$ of patients, been characterized as severe atheroma in $7.6 \%$. The vulnerable atherosclerotic plaque was defined as having thickness $\geq 4 \mathrm{~mm}$, ulcerated, or with mobile component. Several autopsy series and retrospective studies of cases and controls have shown an association between aortic arch atheroma and arterial embolism, which was later confirmed by prospectively designed studies [6]. The presence of mobile thrombus at the STJ was identified as a cause of stroke in the current case. It's worth mentioning, that STJ is a vulnerable hemodynamic area, where maximum blood flow rate is observed [7].

Another important feature of the current case is the myocardial involvement. Simultaneous acute cardiocerebral infarction is a great management challenge for physicians. The incidence is currently unknown due to the rarity of this co-occurrence. There is no clinical trial or a consensus guideline for the management of such patients. The presence of myocardial infarction is a relative contraindication for use of recombinant tissue plasminogen activator in stroke patients, however, it is not evidencebased. The main concerns about giving thrombolytics to these patients are the potential myocardial wall rupture, postmyocardial infarction pericarditis that may become hemorrhagic, and embolization of possible left ventricular thrombi due to lysis [8]. Mechanical thrombectomy is an alternative technique which can be considered for these patients, as it was chosen in the current clinical case.

\section{Conclusions}

To sum up, the present clinical case documents an episode of fatal simultaneous cardio-cerebral embolism of a thrombus inserted at the sinotubular junctionof aorta in a 40-year old apparently healthy female. The rupture of 


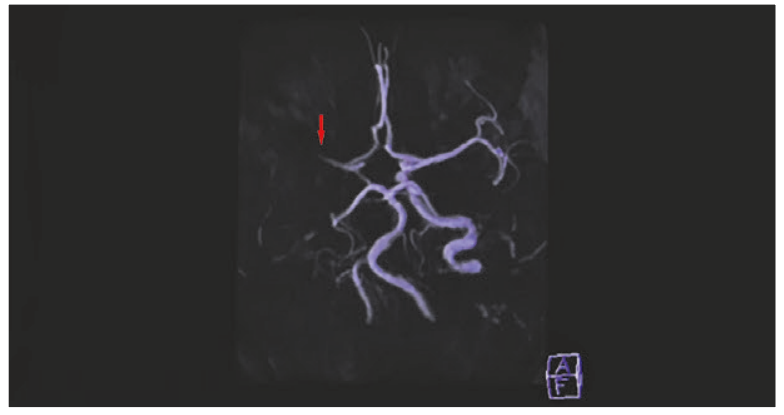

Fig. 1. Three-dimensional reconstruction of the cerebrovascular system by computer tomography showing the occlusion $(\downarrow)$ of the right middle cerebral artery.

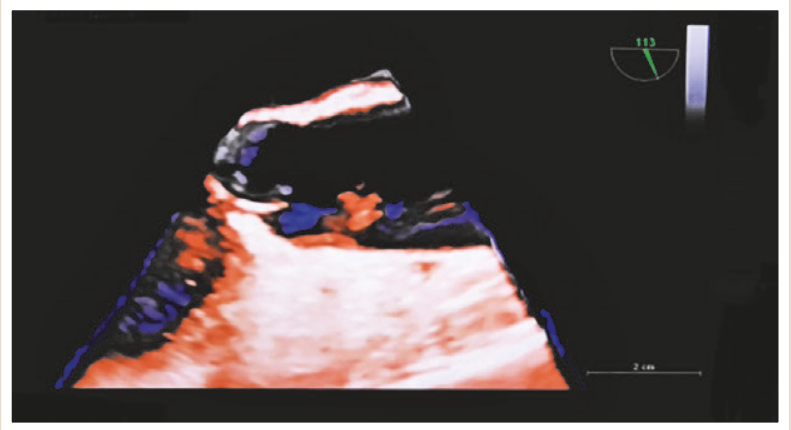

Fig. 3. Three-dimensional transesophageal echocardiography demonstrates long-axis view of ascending aorta with mobile thrombotic formation $(18 \times 19 \mathrm{~mm})$ attached to the sinotubular junction of the right aortic sinus.

Watch additional supplementary video file 2 online (https://youtu.be/XCliflas7Ew).

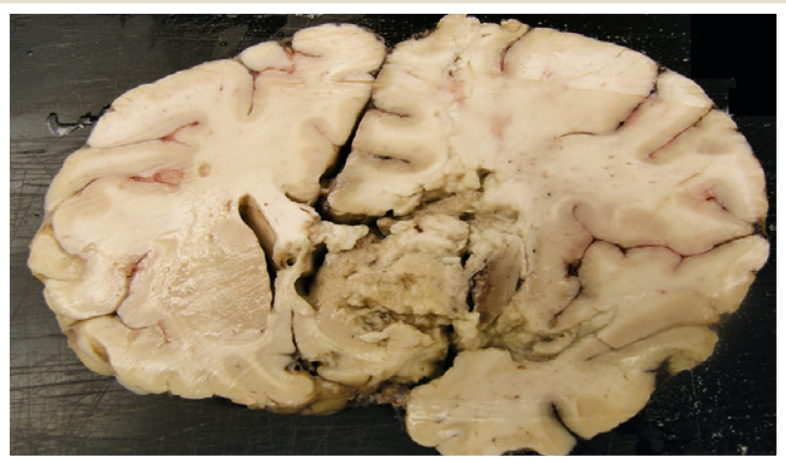

Fig. 5. Autopsy findings of extended right-lobe median cerebral infarction with central displacement.

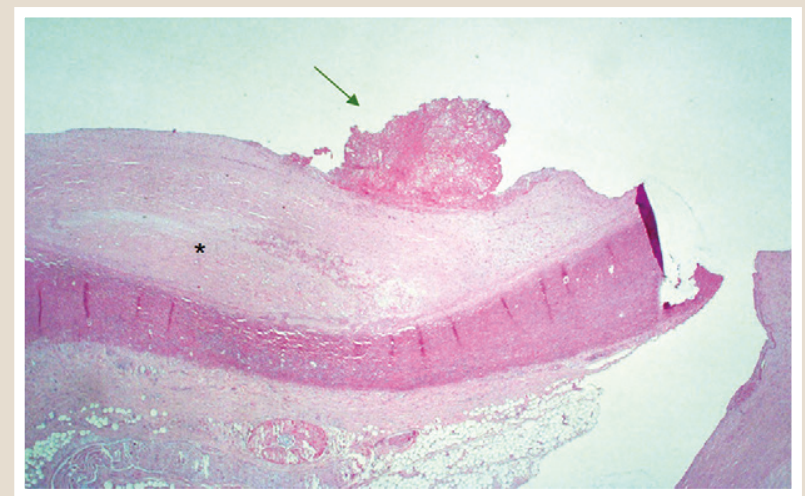

Fig. 7. Histological appearance of a residual thrombus $(\rightarrow)$ on atheroma $\left({ }^{*}\right)$ at the sinutubular junction of ascending aorta. Hematoxylin and eosin staining, original magnification $\times 40$.

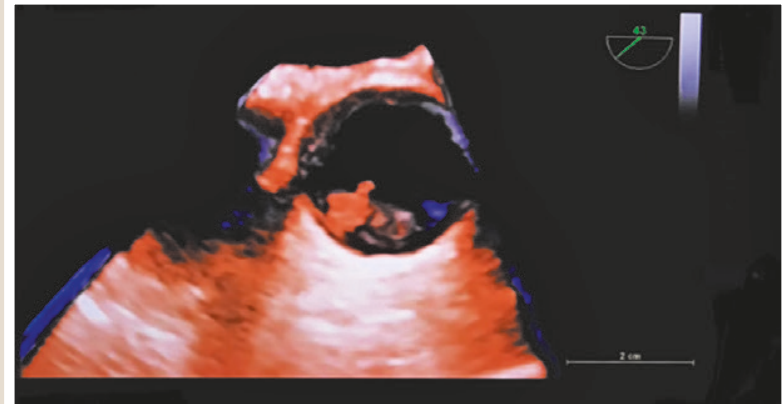

Fig. 2. Three-dimensional transesophageal echocardiography demonstrates shortaxis view of ascending aorta with mobile thrombotic formation $(18 \times 19 \mathrm{~mm})$ attached to the sinotubular junction of the right aortic sinus.

Watch additional supplementary video file 1 online (https://youtu.be/MTqoHkU5uKE).

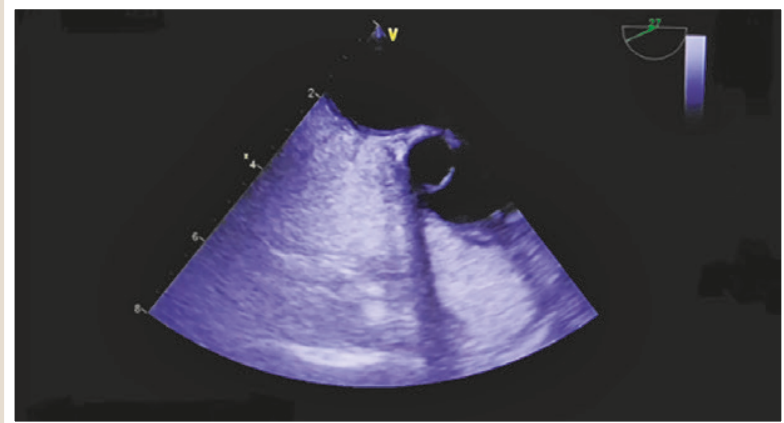

Fig. 4. Transesophageal echocardiography contrast study with agitated saline (bubble study), showing an intactinteratrial septum without any shunts.

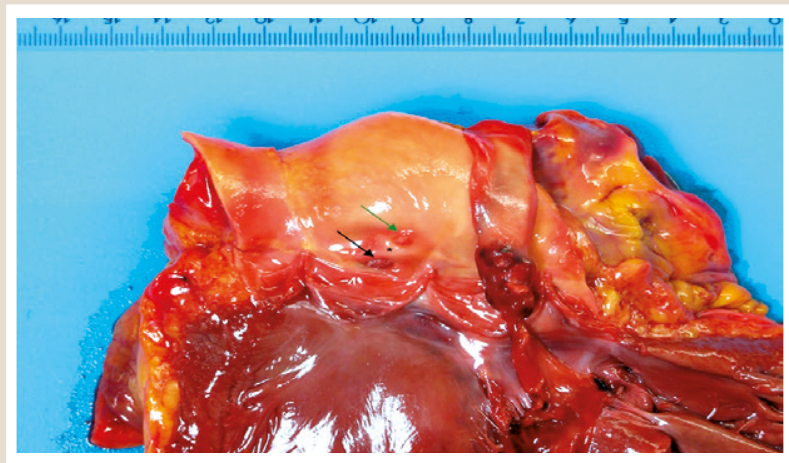

Fig. 6. Autopsy findings of ascending aorta with aortic valve. Thrombus $(\rightarrow)$ on atheroma $\left.{ }^{*}\right)$ near theostium of right coronary artery $(\rightarrow)$

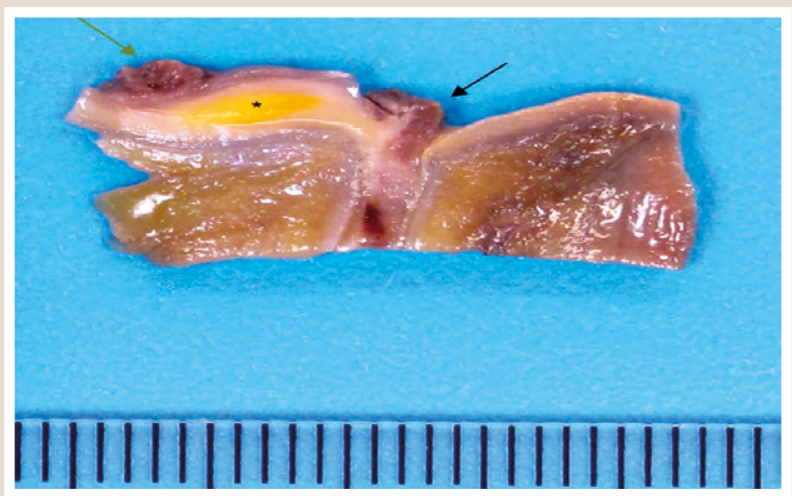

Fig. 8. Autopsy findings of thrombus $(\rightarrow)$ on atheroma $\left(^{*}\right)$ and the right coronary artery $(\rightarrow)$ in longitudinal section. 
a single atherosclerotic plaque led to dramatic course of disease in a young woman without risk factors and negative previous cardiovascular history.

Conflicts of interest: authors have no conflict of interest to declare. Конфлікт інтересів: віАсутній.

Нааійшла Ао реАакції / Received: 03.03.2020

Після Аоопрацювання / Revised: 11.03.2020

Прийнято АО Аруку / Accepted: 13.03.2020

Information about authors:

Vladyslav Kavalerchyk, Helios Kliniken Schwerin, Klinik für Kardiologie und Angiologie, Schwerin, Germany; senior physician. ORCID ID: 0000-0001-7450-8593

Mykhailo Kolesnyk, MD, PhD, DSc, Professor, Department of Family Medicine, Therapy, Cardiology and Neurology, Faculty of Postgraduate Education, Zaporizhzhia State Medical University, Ukraine.

ORCID ID: 0000-0001-7566-1899

Michael Woehlke, MD, Helios Kliniken Schwerin, Institut

für Pathologie, Schwerin, Germany; senior physician.

Alexander Staudt, Professor, MD., Helios Kliniken Schwerin, Klinik für Kardiologie und Angiologie, Schwerin, Germany; chief doctor. Andreas Hagendorff, Professor, MD., Universitätsklinikum Leipzig, Klinik und Poliklinik für Kardiologie, Leipzig, Germany; senior physician. ORCID ID: 0000-0001-6288-7565

\section{Відомості про авторів:}

Владислав Кавалерчик, клініка Helios Schwerin, киініка кардіології та ангіології, м. Шверін, ФРН, старший лікар. Колесник Михайло Юрійович, А-р меА. наук, професор каф. сімейної медицини, терапії, карАіології та неврології ФПО Запорізького Аержавного медичного університету, Україна. Міхаель Вьольке, доктор медицини, клініка Helios Schwerin, інститут патології, м. Шверін, ФРН, старший мікар. Александр ШтауАт, професор, Аоктор медицини, кмініка Helios Schwerin, киініка кардіології та ангіології, м. Шверін, ФРН, головний мікар.

Андреас Гаґендорфф, професор, доктор медицини,

Університетська клініка Лейпцига, киініка та поліклініка кардіології, м. Лейпциг, ФРН, старший лікар.

\section{Сведения об авторах:}

Владислав Кавалерчик, кииника Helios Schwerin, клиника карАиологии и ангиологии, г. Шверин, ФРГ, старший Аоктор. Колесник Михаил Юрьевич, А-р меА. наук, профессор каф. семейной медицины, терапии, карАиологии и неврологии ФПО, Запорожский госуАарственный меАицинский университет, Украина.

Михаэль Вельке, доктор медицины, клиника Helios Schwerin, институт патологии, г. Шверин, ФРГ, старший Аоктор.

Александр ШтауАт, профессор, Аоктор меАицины, клиника Helios Schwerin, клиника кардиологии и ангиологии, г. Шверин, ФРГ, главный врач.

Анареас Хагенаорфф, профессор, Аоктор меАицины, Университетская клиника Лейпцига, клиника и поликлиника кардиологии, г. Аейпциг, ФРГ, старший врач.

\section{References}

[1] Smajlović, D. (2015). Strokes in young adults: epidemiology and prevention. Vascular Health and Risk Management, 11, 157-164. https:ll doi.org/10.2147/VHRM.S53203

[2] Varona, J. F., Guerra, J. M., Bermejo, F., Molina, J. A., \& Gomez de la Cámara, A. (2007). Causes of Ischemic Stroke in Young Adults, and Evolution of the Etiological Diagnosis over the Long Term. European Neurology, 57(4), 212-218. https://doi.org/10.1159/000099161

[3] Stack, C. A., \& Cole, J. W. (2018). Ischemic stroke in young adults. Current Opinion in Cardiology, 33(6), 594-604. https://doi.org/10.1097/ hco.0000000000000564
[4] van Alebeek, M. E., Arntz, R. M., Ekker, M. S., Synhaeve, N. E., Maaijwee, N. A., Schoonderwaldt, H., van der Vlugt, M. J., van Dijk, E. J. Rutten-Jacobs, L. C., \& de Leeuw, F. -E. (2017). Risk factors and mechanisms of stroke in young adults: The FUTURE study. Journal of Cerebral Blood Flow \& Metabolism, 38(9), 1631-1641. https://doi. org/10.1177/0271678x17707138

[5] Agmon, Y., Khandheria, B. K., Meissner, I., Schwartz, G. L., Petterson, T. M., O'Fallon, W. M., Whisnant, J. P., Wiebers, D. O., \& Seward, J. B. (2002). Relation of coronary artery disease and cerebrovascular disease with atherosclerosis of the thoracic aorta in the general population. The American Journal of Cardiology, 89(3), 262-267. https:// doi.org/10.1016/s0002-9149(01)02225-1

[6] Pujadas Capmany, R., Oliveras Ibanez, M., \& Jane Pesquer, X. (2010). Complex Atheromatosis of the Aortic Arch in Cerebral Infarction. Current Cardiology Reviews, 6(3), 184-193. https://doi org/10.2174/157340310791658712

[7] Numata, S., Itatani, K., Kanda, K., Doi, K., Yamazaki, S., Morimoto, K Manabe, K., Ikemoto, K., \& Yaku, H. (2016). Blood flow analysis of the aortic arch using computational fluid dynamics. European Journal of Cardio-Thoracic Surgery, 49(6), 1578-1585. https://doi.org/10.1093/ ejcts/ezv459

[8] Fugate, J. E., \& Rabinstein, A. A. (2015). Absolute and Relative Contraindications to IV rt-PA for Acute Ischemic Stroke. The Neurohospitalist, 5(3), 110-121. https://doi.org/10.1177/1941874415578532 